\title{
ToxicDocs: using the US legal system to confront industries' systematic counterattacks against public health
}

\author{
Sheldon Whitehouse ${ }^{1}$
}

(C) Macmillan Publishers Ltd., part of Springer Nature 2018

In the United States legal system, discovery can be a powerful tool. Courts allow plaintiffs to gather evidence from defendants through depositions, written questions, or access to relevant documents. As Gerald Markowitz and David Rosner have proven time and again, it is discovery that often leads to the smoking guns buried deep within corporate records.

With ToxicDocs, Markowitz, Rosner, and Chowkwanyun combine the reach of discovery with the capabilities of big data technology to provide a rich new resource for researchers, journalists, and public health advocates. [1] Unlocking the secrets of corporate archives can level the field between polluters and victims of industrial contamination.

When, as Rhode Island's Attorney General, I pursued a civil suit against the lead pigment companies, Markowitz and Rosner dug through millions of company memos, newsletters, and other documents acknowledging the danger of lead-based paint. Corporate records identified lead as a "deadly cumulative poison." Trade association meeting minutes catalogued discussions on childhood lead poisoning.

At the time, the rate of lead poisoning in Rhode Island was twice the national average. Providence, the capital city, was referred to as "the lead paint capital of the United States." Rhode Island's Director of Human Services, Christine Ferguson, called lead "a silent thief that steals the potential of our children."

Even though Rhode Island's children were under attack from this silent, invisible poison, industry lobbyists had successfully tied the legislature and state house in knots. Fortunately, the courts provided recourse for ordinary citizens in the face of paralysis or indifference in the legislative and executive branches. The pigment manufacturers' battery of lawyers mounted a fierce defense. But thanks in no small

Sheldon Whitehouse

http://www.whitehouse.senate.gov/contact/email-sheldon

$1 \quad$ United States Senate, Providence, Rhode Island and Washington, DC, Hart Senate Office Bldg., Rm. 530, Washington, DC 20510, USA 
part to Markowitz and Rosner's testimony on the industry's own damning documents and the propaganda campaign that prolonged and worsened the tragedy, a jury of six Rhode Islanders saw through all the smokescreens and legal shenanigans to find the defendants liable.

While, regretfully, the lead pigment makers were ultimately able to slip free of that verdict, Markowitz and Rosner returned to the stand in a 2013 California lawsuit that held three pigment companies liable to pay $\$ 1.1$ billion to remove leadbased paint from homes in that state.

The testimony of Markowitz and Rosner in these cases revealed not only the public health problem of lead paint, but also the structural problem of industry counterattacks against public health. These campaigns used methods, strategies, and institutions that are common across a wide variety of hazards, including tobacco, climate change, and the dangerous chemicals that lace the air we breathe and the products we buy.

ToxicDocs tells the story of the ongoing effort to discredit public health concerns so major industries can continue to pollute and profit from dangerous products. Jerry and David deserve great credit for helping to bring that important story to light.

\section{Reference}

Rosner D, Markowitz G, Chowkwanyun M. Guest Editorial: ToxicDocs (www.ToxicDocs.org): From history buried in stacks of paper to open, searchable archives online. J Public Health Policy [special section] "ToxicDocs: Opening a new era of evidence for policies to protect public health" (Guest Eds. Rosner D, Markowitz G, Chowkwanyun M). 2018;39(1). https://doi.org/10.1057/s41271-0170106-8.

Sheldon Whitehouse is a US Senator representing the state of Rhode Island since January 2007 and formerly that state's Attorney General and US Attorney. Email: www.whitehouse.senate.gov/contact/ email-sheldon. 